\title{
Malang mignon \\ Cultural expressions of the Chinese, 1940-1960
}

Melani Budianta

Malang, a hilly resort town in East Java, was from the 1950s to the 1960s a city alive with arts and cultural performances. ${ }^{1}$ Born in the 1950 s and raised in a peranakan (culturally assimilated Chinese) culture that nurtured the taste for traditional dances and theatre, my three sisters and I were avid consumers of, and sometimes amateur participants in, the city's cultural festivities. ${ }^{2}$ My father, as a board member of the Malang branch of an association of cigarette companies (Gabungan Perusahaan Rokok or GAPERO), often got free tickets to the best shows in town. ${ }^{3}$ Cigarette companies - along with other businesses owned by the Chinese - were regular patrons of such activities. There was a rich variety from which to choose, from our most favourite wayang orang Ang Hien Hoo, traditional Javanese theatre owned and played by the peranakan Chinese, to ludruk (a comic popular theatre form from East Java) and the Chinese puppet shows at the Malang Chinese temple. Modern and traditional dances from all parts of Indonesia, as well as ballet and folk dances from many countries were performed in cultural nights sponsored by the many competing political parties and cultural organizations.

Towards the mid-1960s, however, when the ideological competition between right-wing and left-wing politics was on the rise, we

1 I am indebted to Soebianto Hudyana (Liem Tiauw Bian), writer on Chinese Indonesian issues, for his encouragement and help in collecting research materials, checking the accuracy of my data, connecting me to resource persons, and for his assistance during interviews. I am grateful to all interviewees, who have generously shared their stories, documents and photos.

2 Of the seven children in our family, four of the five girls were born in the 1950s (1950, 1951, 1954, 1957).

3 Tan Hong Bok (born in Pare 1919) moved to Malang in 1947 and served in the management of Toegoemas cigarette company, was board member of the Association of Cigarette Companies (Gabungan Perusahaan Rokok, GAPERO) in Malang, and member of the advisory board of a number of Catholic social and educational foundations in Malang in the 1950s-1960s. 


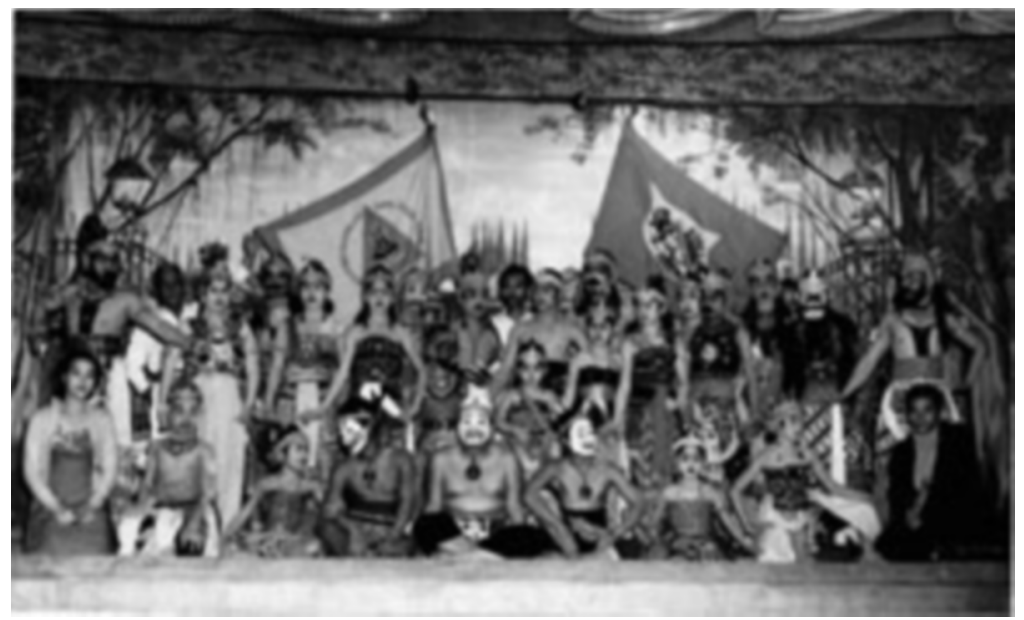

Ang Hin Hoo Wayang Orang Theatre Group in the 1950s. (courtesy Tjia Tjhoen Liem, Bandung)

learned that stepping into cultural festivals of a wrong camp could lead to an uneasy situation. One night, my three sisters and I were attending one cultural festival that showed lively dances of fishermen, farmers at harvest, and Chinese folk dances. What we did not expect was that after every performance, the crowds would stand up and yell, shouting things like, 'long live President Soekarno' or 'long live Chairman Mao', and other apparently rehearsed political yells with appropriate gestures of raised fists, with which we were not familiar. Embarrassed, we remained glued to our chairs and got nasty stares from the audience. We left early that night.

This essay is a part of my intellectual quest to reconstruct the cultural dynamics of the Malang Chinese in their hey-day in the 1950 s and their critical transition in mid-1960s. It aims to understand the context and forces that shaped the diverse cultural articulation, the complex tensions and fusion of culture and politics at the time, and the marked shift after the country was shaken by the 1965 political upheaval. This is a social and cultural history with small caps. Cultural festivals and performances by the Chinese were mostly urban pastimes, which were not intended as highbrow artistic achievements. So far, what I have amassed - patches of personal memories of hobby-club members and networks of friendship that continued despite ideological differences - amounts to snapshots of everyday life in a small town. 
In tracing the cultural history of the Chinese in Malang, I am using my own personal memory and the memories of my father's generation, making use of the network of relatives, their friends, and friends of friends. ${ }^{4}$ In doing so, I am reconstructing a web of social relations of a larger dimension. Many of the people I interviewed had left the city many years previously. Their memories of living in Malang sometimes overlapped, and sometimes represented different time periods, as key events, memorable places and people emerged and the segments of a bigger social and historical perspective began to take shape. With the distance of time and space, many of them shared their conscious reflection of what the Chinese communities in Malang meant to them. In the words of Crishohn (2001:195) citing Halbawchs, it is 'a matter not just of consciously lived time but of socially lived space and the collective representation of that space'.

This essay shows how the social and cultural fabric of Chinese communities in this small town in East Java in the 1950s and 1960s was held together by a mixture of Dutch-Malay-Chinese-Javanese cultural milieu, despite differing political or ideological positions. The collected memories of opa and oma, tante and oom in Malang reveal the way daily life was indirectly connected to the forces of the nation embroiled in Cold War politics. It is a cultural history from below, which will complement both studies on the political scene of the 1950s and 1960s and macro-scale studies on Indonesian Chinese. By connecting the politically divisive 1960s to the fluid cultural dynamics in the daily life among the Chinese communities in Malang in the 1950s and 1960s, this study complicates the accepted dichotomies of assimilationist versus integrationist, or Left versus Right, which loom large in discussion to date about the Indonesian Chinese and the political scene of 1960s Indonesia.

In its focus on Malang as research site, this essay is comparable to historical and sociological studies on specific sections of Indonesian Chinese communities in Yogyakarta and Surakarta at different times (Didi Kwartanada 2002; Rustopo 2007). Highlighting the structures of feeling of the fifties and sixties, my micro-scale research also complements and puts a cultural angle on the dominant political and macro perspective about the Indonesian Chinese in this period (Coppel 1983; Heidhues 1988; Leo Suryadinata 2002).

4 Starting with my peranakan family that is culturally assimilated and lost cultural ties to China, my journey took me to meet others in Chinese speaking families, ones that are generally termed as totok or the more recent migrants. Initially focusing only on the peranakan culture, I soon found out that the boundary between the peranakan and totok categories was porous, and it would be more fruitful for me to see the interaction of the Chinese in Malang, from diverse backgrounds, through the arts and cultural scene. 
I begin by looking at Malang from the beginning of the nineteenth century as the transit site for Chinese migration to and from other cities in East Java, with their hybrid culture. Then I contextualize the migration in the complicated power struggle of the revolutionary era, showing the importance of the experience in shaping the generations of Chinese who later played a significant role in the cultural scene of the 1950s and 1960s. I trace different generations of Chinese intellectuals and literati who shaped or were shaped by the Malang cultural scene, many of whom later played a role at the national level. The main thrust of the essay is my discussion of the various cultural groups and associations emerging in the 1950s, with diverse and usually competing goals and cultural orientation. I examine how they negotiated with larger forces, which climaxed in the 1965 communist-cleansing tragedy.

Surrounded by hills and volcanic mountains, Malang, which is 80 miles to the south of the harbour city Surabaya, has been known since colonial times for its plantations (tea, coffee, sugar, and sweet potato), and as a residential and resort area. Linked with railroads and invested with good infrastructure, the Dutch government gave it the status of a municipal government in 1914.

The population of Malang grew with the growth of the city, attracting Chinese migrants. In 1890, when Malang's total population was 12,040 there were 1,542 Chinese, making them the second largest group after the 'natives' (inlander). ${ }^{5}$ By 1940 , the number of Chinese migrants had increased to 12,233 out of the total population of 169,316 although they were now outnumbered by the Europeans - the number of whom had grown from 459 to 13,867 in 50 years (Van Schaik 1996:29). This demographic data shows the strong growth of European presence in the colonial era. The nature of Malang as a Dutch residential and administrative town encircled by Dutch administered onderneeming (plantations) nurtured the Dutch-speaking milieu amongst the peranakan Chinese, who were mostly educated in the Dutch school system.

The social and cultural history of the Malang Chinese can be traced from the hong boen (funeral association) called Ang Hien Hoo (established in 1910), which used the Eng An Kong Temple as its

5 There were four official categories, Natives, Chinese, Foreign Orientals, and Europeans (Van Schaik, 1996:29). 
headquarters. ${ }^{6}$ As in other cities in Asia, the Chinese temple, besides having a religious function, became the centre of social and cultural activities that began with the need to give decent burial ceremonies and facilities to the Chinese migrants. ${ }^{7}$ The spread of funeral associations throughout Java in the 1900s occurred at the same time as the establishment of social organizations such as Tiong Hwa Hwee Koan, which founded schools for Chinese migrants. Coppel (1994) notes that the underlying force of this initiative was the awakening of Chinese nationalism among Chinese migrants, which was later counterbalanced by the establishment of the Hollandsch-Chineesche School (HCS, Dutch Chinese Schools) by the Dutch in 1908. Children graduating from HCS could go to the junior secondary school (Meer Uitgebreid Lager Onderwijs or MULO) and later to the senior secondary school (Algemene Middelbare School or AMS), which were both popular with Chinese students of middle-class background in Malang.

The influence of Dutch education, the common bond of sentiment among Chinese migrants, and strong local mooring were strongly reflected in the articles published in the 25th anniversary book of Ang Hien Hoo, the hong boen association at the Ang En Kong temple in Malang (Suma et al. 1935). The anniversary book was written mostly in Dutch-inflected Malay, with a few front pages in Mandarin (Suma et al. 1935). Dozens of well-written articles in Malay submitted from Solo, Surabaya, Madiun, Bandung, Semarang, and various districts in Malang discuss the history of Ang Hien Hoo, connecting it to wide ranging issues, from politics in mainland China to social and cultural issues. In the foreword, the editor of the Gedenkboek (Suma et al. 1935:1) addresses the issue of differences amongst the Chinese migrants:

The birth of Ang Hien Hoo was based on 'democracy', the principle upon which this association opened its door to different groups of ethnic Chinese without considering whether they were rich or poor, totok or peranakan. As long as they behaved well, they could join the association. No wonder that the birth of Ang Hien Hoo then solved the complicated problems of the ethnic Chinese. ${ }^{8}$

6 The Eng An Kong temple in Malang was built in 1825.

7 The funeral associations or hong boen spread in the early 1900s in many cities in Java, starting in Batavia, then Semarang, Pekalongan in Central Java, Surabaya, Probolinggo, Pasuruan, and Malang (Suma et al. 1935).

8 Krana lahirnja Ang Hien Hoo ada mengambil dasar 'democratie' dimana itoe perkoempoelan memboeka pintoenja boeat berbagi-bagi golongan Tionghoa zonder pandeng soeal kaja dan miskin, totok dan pranakan asal berklakoean baek bisa ditrima mendjadi anggotanja, maka tida oesa diboeat heran kapan lahirnja Ang Hien Hoo lantas banjak mengilangkan kakoesoetannja sia-hwee Tionghoa di itoe waktoe. 
The article addresses the heterogeneity of the Malang Chinese, in particular the cultural division between the peranakan Chinese and the totok Chinese. In general, the two terms differentiate between older migrants who were assimilated to local cultures from those newer migrants with closer cultural affiliation towards China. As social constructions, these terms had no clear cut boundaries, yet they were terms of social differentiation which were used by the Chinese in Indonesia to categorize cultural differences among themselves. Language was one of the most apparent markers. Inability to speak Mandarin or one of the Chinese dialects was an indication that one was culturally distanced from one's homeland. There was mutual prejudice and condescension between the two groups, as difficulty of communication and different cultural milieus set them apart. However Ang Hien Hoo, in its organization as hong boen and its varied cultural productions (Chinese puppet shows and dragon dances, Javanese wayang orang and gamelan music), served as a cultural space for these two groups to interact and work together.

The anniversary book, half of which comprised advertisements of various companies in Malang (and a few from Surabaya), shows the middle-class base in Malang in the 1930s, with businesses serving as patrons for social and cultural activities. It also reveals existing networks of Chinese living in Java based on Chinese social organizations. Most obvious is the strong role of the educated peranakan Chinese, who spoke Malay and Dutch. The book exemplifies the way that Malang in the 1930s served as a multicultural site for intellectual and cultural dialogue between Chinese intellectuals, with close ties between Malang intellectuals and those living in the neighbouring East Javanese cities, especially Surabaya.

\section{THE AMT GENERATION AND THE 1947 MIGRATION}

The Japanese Occupation from 1942 to 1945 was a life-changing experience for many Chinese, including those in East Java. Many told stories of their houses being looted, men kidnapped and slaughtered, and families fleeing for safety from one city to another, including to Malang and its neighbouring cities (Soebianto 2008:1). One major cultural policy of the Japanese Occupation was the closing of Dutch schools, which forced many peranakan Chinese to enter Chinese language schools. In Malang, elementary school children from peranakan families were moved from the Dutch school to Chiao Tung Shiee Siauw, the Chinese school, where they got their first orientation to the Mandarin language. Japanese 
authorities also set up an organization called Kakyo Shokay (Association of Migrant Chinese), and Keibotai, (Chinese armed civilians to help Japanese Police) which grouped the totok and the peranakan together, pushing them to interact more closely than before. ${ }^{9}$

During the Japanese Occupation, Chinese intellectuals who had shown resentment against the Japanese Occupation of China faced danger. One of these was Siauw Giok Tjhan, a radical young editor of the Matahari newspaper in Surabaya, who fled to Malang for safety. The exodus of Siauw Giok Tjan and his brother Siauw Giok Bie to Malang was a crucial factor in the subsequent politicizing of Malang Chinese intellectuals. When the Japanese recruited Chinese youth to form a special army called Keibotai, Siauw and other Malang Chinese leaders devised strategies not only for avoiding conflict with the Indonesian armed civilian militia established by Japan, called Keibodan, but also strategies to use the Keibotai to 'awaken in the Chinese youth the awareness of being the Indonesian young generation that should work together with other Indonesian youth to fight for the sake of Indonesian people and achieve national independence'. ${ }^{10}$

In the spirit of the fight for independence, youth organizations sprouted and young people all over Indonesia volunteered to arm themselves, many using the term Angkatan Muda Indonesia (AMI, Indonesian Youth Regiment) (Muhammad Umar Syadat Hasibuan 2008). To show the existence of the Chinese youth, especially at a time when the loyalty of the Chinese was questioned, Siaw Giok Bie and Go Gien Tjwan mobilized Malang Chinese youth by creating the Angkatan Muda Tionghoa (AMT, Peranakan Chinese Youth Regiment). AMT leaders met with Bung Tomo, a militant nationalist fighter from Surabaya who formed a youth civilian army called Barisan Pemberontakan Rakyat Indonesia (BPRI, Indonesian People's Resistance Front), to strategize their moves together with the Indonesian forces. ${ }^{11}$ At the same time, the Keibotai was changed to become the Blue Cross, which sent Chinese youth to rescue the wounded during the revolution, most notably during the 10 November battle against the Dutch army in Surabaya. The Blue Cross supported Indonesian fighters with food and supplies

9 From Santoso Budiman (Kang Biauw Kwie), interview, Malang, 1-8-2009. Also see Siauw Giok Tjhan 1981:72.

10 Siauw 1981:75. Keibotai perlu digunakan 'sebagai penggugah kesadaran pemuda peranakan Tionghoa, bahwa mereka adalah putera Indonesia, yang perlu ikut serta dengan putera-putera Indonesia lainnya untuk memperjuangkan perbaikan nasib bagi seluruh Rakyat Indonesia dan mencapai kemerdekaan nasional.'

11 Go Gien Tjwan, interview, Jakarta, 3-7-2008 and Santoso Budiman, interview, Malang, 1-82009. 
sent via the Surabaya-Malang train, and helped remove the sick and the wounded from the battlefront to safer areas in Mojokerto, Pasuruan and Malang (Siauw 1981:77-8).

During these revolutionary years, the Japanese-enforced policy to group all Chinese students in one educational system was abandoned. Students oriented towards China went to Chinese schools. Meanwhile, anticipating that the Dutch school system would be reinstalled, teachers and ex-students of the Dutch school from preJapanese Occupation days used the umbrella of the AMT to create a 'crash course' to catch up with what they had missed. From 1946 to 1949, most of the AMT 'crash course' alumni left Malang to continue their university studies in Surabaya, Jakarta or the Netherlands. ${ }^{12}$ The AMT educational service was the nursing bed of Chinese Indonesian professionals, entrepreneurs and intellectuals in the Old and New Order eras, such as Tan Hoo Tong, who in the late 1950s was appointed as Indonesian ambassador to Hungary and Liem King Hok, who served at the Ministry of Finance during the New Order. The AMT generation - the political as well as the educational wing - were mostly Dutch-speaking peranakan Chinese, who later occupied different if not opposing roles and ideological positions in Indonesian history. Go Gien Tjwan and Siauw Giok Tjhan became state officials of the Soekarno era, ${ }^{13}$ Siauw Giok Bie led the Malang branch of Badan Permusyawaratan Kewarganegaraan Indonesia (BAPERKI, Council for Deliberations on Indonesian Citizenship), and Oey Hay Djoen, became a Partai Komunis Indonesia (PKI, Indonesian Communist Party) activist in Yogyakarta and Jakarta. All three were later persecuted as leftists and imprisoned during the New Order. Many other AMT crash course alumni were conscripted or volunteered to serve in the Indonesian military for a certain period in their lives, and some even served in the Army detention unit during the communist cleansing era of the mid-1960s. ${ }^{14}$

12 Amongst hundreds of the AMT students were Han Hoo Tjwan (Han Awal), one of Indonesia's leading architects who helped design the Conference of New Emerging Forces (CONEFO) project in 1960s and received awards for the conservation of the National Archives building and Dutch colonial buildings in the 1990s; Liem Siok Ien, who worked as an engineer in the Indonesian Navy; Willy Halim Indrakusuma, a dentist, who later owned leading travel agencies; Tjan Hong Tjhiang, now a retired chemist from Unilever, who once served in the Navy as head of 1965 convict detention unit. For a more detailed biography of the individuals mentioned in this essay, see Sam Setyautama 2008.

13 Go Gien Tjwan left Malang in 1947 to work for the Ministry of Foreign Affairs in Jakarta before going to the Netherlands for his studies, and upon his return to Jakarta in 1955 served as Director of the National News Agency, Antara (interview, Jakarta 3-7-2008). See Siauw's memoir (1981).

14 AMT crash course alumni, Focus Group Discussion, Jakarta 22-1-2009. 
At the same time as many members of the AMT generation were leaving Malang, there was another wave of incoming migration of Chinese from neighbouring cities (including Kediri, Pasuruan, Nganjuk, Jember, Blitar and Pare) to Malang in 1947, during the first Dutch military aggression. Most of the peranakan Chinese in these neighbouring communities made a living from trading and distributing agricultural crops in villages and small towns (Yang 2004). It was a chaotic time, when the Indonesian military was pulling all forces to fight the Dutch. The militia were on the loose and the country was divided into Dutch occupied regions and regions belonging to the Republic. To protect their lives and belongings, some Chinese communities armed themselves, or moved to the Dutch occupied area, causing further questioning of their loyalty. Some were forced by armed civilians to migrate and had their belongings looted, and many were killed (Stanley and Arief W. Djati 2004).

The 1947 migration caused a demographic shift in the city. When the Dutch military occupied the city in 1947, they let the homeless Chinese migrants from neighbouring areas stay in empty houses vacated during the Japanese Occupation by their former Dutch owners, or left by the Indonesian military officers who had probably taken them from the Dutch. The elite residential areas in Malang - the streets of Ijen, Dempo, Raung, Panderman - were thus distributed to the new Chinese migrants, who later registered with the housing office ${ }^{15}$ and acquired legal documents. ${ }^{16}$ Most of the new owners in the central and southwest areas of Malang were Dutch-educated peranakan Chinese, who were professionals working as doctors and consultants, managers or directors of the industries, or middle-class entrepreneurs. Less well connected migrant peranakan Chinese spread in pockets of unoccupied spaces in the eastern part of the city. ${ }^{17}$ The Mandarin speaking Chinese or totok

15 In the 1940s, the housing offices called Versluis and Hom gave the new owners permits to use the houses and collected rents. These were originally Dutch institutions, which in the revolutionary period were still operating, most possibly taken over by local staff.

16 An article titled 'Perkembangan penduduk dan persoalan-persoalannja' (Population growth and its problems) in the 50th anniversary book published by the Malang municipality in 1964 discussed this demographic shift as an unresolved problem of the city, whereby 'the Chinese with the back-up of strong capital, and still owning wealth under legal protection before the revolution, occupied a great spread of the formerly Dutch occupied residential area' (Masjarakat Tionghoa dengan modal jang kuat dibelakangnja dan masih memiliki kekajaan dibawah undang2 jang legal sebelum revolusi, menduduki bagian tersebar dari perumahan2 Balanda tersebut). The writer believed that there would be a future of 'revolutionary changes for public welfare, and not for one class' (pastilah dihari hari jang akan datang hal ini akan mengalami perobahan2 jg revolusioner menudju kepada kepentingan umum dan bukan buat satu golongan). See Mochamad Hanafiah et al. 1964:56.

17 Ariel Heryanto, interview, Jakarta, 19-11-2009. 
resided closer to the trading and business areas in the Chinatown and its adjacent areas. ${ }^{18}$

THE 195 OS GULTURAL SCENE

Arts and culture of the 1950s in Malang reflected the needs of the urban middle-class population, including the Chinese. Unlike Surabaya, which grew to be a bustling business and trading centre in Java, Malang retained its character as a residential area. Plantations and cigarette companies became two of the most flourishing industries. Other businesses catered to the leisure and lifestyle of the growing urban middle class, such as the garment and fashion industry, flower shops, photo studios, restaurants, house and building appliance suppliers, printing and publishing. Many of the residents were white-collar professionals (medical doctors, dentists, lawyers, accountants), who acquired money and time to spend on leisure activities. ${ }^{19}$ The cigarette industries - and their association called GAPERO - became the backbone of cultural philanthropy in Malang, funding arts, cultural, social and educational activities particularly.

In the $1950 \mathrm{~s}$, the heterogeneous Chinese population, both totok and peranakan, had clubhouses and informal groups to organize leisure activities, such as sports, theatre, dance and music. The Cantonese who lived in the trading area had their own club house, which showed theatre, dance and music in their own tongue. ${ }^{20}$ The Mandarin-speaking population had various associations, such as Sheng Huo Hsuch You Hui, Chung Hua Tsung Hui, Shin Li She, Giok Yong Kong Hui, Kung Chao Hui Hui Koa, Tsing Niem Hui and the women's association of Hwa Djian Fu Ni Hui (Gapar Wirjosoedibyo et al. 1954:133).

The popular sport for the middle-class Chinese directors, managers and professionals in Malang was tennis. In the early 1950s they formed two tennis clubs called STAR and Rukun, and built five

18 There were exceptions to this generalized pattern. Some Mandarin and Hokkien speaking families who were well connected also resided in the elite residential area, where the Dutch used to live. At the same time, not all families residing in this area were well off.

19 In 1950 the Chinese population in the city numbered 11,451 a decrease of around 800 from the recorded population of 12,323 in 1940 (Stanley 2004). The Chinese population later grew to 29,402 (of a total population of 445,000 ) by the end of 1968 .

20 Go Ing Hok (interview, 13-17-2010) often watched the Chinese opera in Cantonese in the Cantonese club house near his house in the Chinatown area. Most of the Cantonese migrants were carpenters working for furniture shops. 
tennis courts on Jl. Pahlawan Trip. While Rukun served to breed young amateur tennis players, STAR provided a leisure space for family gatherings and socializing. Costume parties, in which families donned costumes of different ethnic groups (Balinese, Sumatran and so forth), comic trans-dressing, and friendly tournament trips to other cities were some of the STAR favourite events. Another well-known hobby club founded in the 1950s was the Perkumpulan Olah Raga, Seni Tari dan Dharmawisata (POSTD, Organization for Sports, Dance and Tourism), which organized mostly sports activities, such as table tennis and badminton for its members.

One of the most prominent clubs where peranakan Chinese 'celebrities' gathered for cultural exposure was the Pusat Pergaulan Umum (PPU, Social Centre), with dance (especially ballroom dancing), musical group bands (one of which was the Hawaiian Band called KES or 'Kloek en Sterk' ('Courageous and Strong'), and theatrical performances as their main activities, using the auditorium on top of the Rex movie house on Jl. Kabupaten as their meeting place. ${ }^{21}$

A main attraction of the PPU was amateur Malay toneel or theatre, which was already well established in Malang. One patron of Malang's amateur theatre was Fred Young, a well-known theatre and film director in the 1950s who owned the Rex movie house where many of the PPU social and cultural activities took place. ${ }^{22}$ Another influential figure in amateur theatre in Malang was Njoo Cheong Seng, a prolific novelist, playwright, screenwriter, theatre and film director from the 1930s. ${ }^{23}$ Njoo Cheong Seng had travelled the world with his second wife and popular actress Fifi Young, and had a long history with theatre groups in the 1930s and 1940s such as Miss Riboet's Orion and Dardanella, before settling during the Japanese Occupation in Malang, where he married his fourth wife, Huang Lin, a Mandarin teacher turned amateur actress. According to Myra Sidharta (2004), 'Njoo found the most suitable intellectual atmosphere in Malang' and established an intellectual circle that

21 Peranakan Chinese who did not belong to this milieu used to sneer at the club's 'Western' orientation, by giving its abbreviation, PPU, a new interpretation, Pepet-pepetan udel (navelrubbing, mocking the 'improper' way young men and women hugged each other in ballroom dances), Tjia Tjoen Liem and Tjia Liang Koei, interview, Bandung, 31-1-2009.

22 Fred Young, a screenwriter and film producer, was born in Semarang in 1900 and later moved to Malang. He joined the Bintang Soerabaja theatre group in 1941 and was active in its theatre production until 1948. From 1949 to 1954 he produced nine films under the Bintang Soerabaja film company, most possibly an extension of the theatre group. Later he went on to found his own film company, serving as producer, director and screenwriter until 1975. He died in Malang in 1977.

23 Njoo Cheong Seng and Fred Young had collaborated in theatre as well as film production, before and during the 1950s. 
included photographer Ong Kian Bie and writer and illustrator Tan Liep Poen..$^{24}$ Throughout the 1950s, Njoo Cheong Seng was active in directing plays performed by amateur players who were also PPU members. ${ }^{25}$

One of the most staged plays in the 1950s was Njoo Cheong Seng's Malang mignon (or Malang chic, a name the author also used for his flower shop in Malang in his retirement), a 'melodrama in 4 acts', performed for the first time by amateur group in Malang. Malang mignon was premiered in Malang on 23-24 January 1951, commissioned by the Ma Hua Hsiau Yu Hui school, which shows how the totok and the peranakan worlds coalesced in local theatre. The play was directed by the author, Njoo Cheong Seng himself (under the pen name of M. d'Amour), who was entering the 'amateur' world for the first time after 29 years of earning his living with professional groups (d'Amour 1951:84). The melodrama depicted the tragic life of Giok Hoa, a sweet but sickly young wife with two children, whose husband, Sing Tjiang has been having an affair with his childhood first love turned modern femme fatale, namely Bonita Fonk or the 'Malang mignon'. The melodrama was a tear-jerker in its portrayal of the suffering of the two children at the hands of the cruel stepmother Bonita after Giok Hoa dies of a broken heart, later followed by the death of her beloved son Armand.

The play's theme, a warning against the lure of the flesh away from family responsibility, had been a common theme in the popular Malay novels written by the peranakan Chinese from the early twentieth century. Similarly the evil lure embodied in a young woman who has been led astray by modern ways was a familiar plot. The play is interesting in its mixing of languages and cultural references, which was a phenomenon that characterized the peranakan Chinese world. The dominant language register of the play is poetic Malay, with a propensity towards syair-like rhyming (a-a), especially in melodramatic moments between the dying mother and her son and daughter. The sentimentality of the play was counterbalanced by two comic characters speaking in colloquial, mixed languages, who were modelled after the American comic characters 'BudAbott and Lou Costello' (d'Amour 1951:88). Representing the

24 For further information on Njoo Cheong Seng's biography and works, see Myra Sidharta (2004:24-51) 'Njoo Cheong Seng; Penulis novel, drama, dan syair' in Dari penjaja tekstil sampai super woman.

25 Malang theatre-goers remembered watching the restaging of Njoo's older plays, Gagak lodra and Djembatan merah which popularized patriotic songs composed by the famous song writer, Gesang. They also recalled watching the plays performed at the theatre house Emma in Malang in 1940s by the professional theatre group called Bintang Soerabaja with Fifi Young, then Njoo's wife and theatre prima donna. 
language spectrum of Malang peranakan Chinese, the clown scene freely mixed Dutch, Hokkien and Javanese diction, and political jargon, with physics and literary terms from the wayang repertoire also blended in, making almost nonsensical noise but showing the intellectual milieu of the peranakan audience. Similarly, the French word mignon and titles of other plays showed references to Western literary tradition.

Besides original plays, the Malang Chinese also staged plays translated from Chinese, such as the famous play Mawar hutan (Rose of the woods), a translation of the play titled Chen Chuen. ${ }^{26}$ Mawar hutan was originally a Chinese propaganda piece against Japanese Occupation. The title of the play was the nickname of a female spy sent to marry a Chinese landlord who worked for the Japanese ruler to quell the Chinese resistance movement. The script used for the PPU performance in the mid-1950s was amended and shortened to erase much of the explicit propaganda, leaving only the romance and the suspense. Both Malang mignon and Mawar hutan showed that in the toneel tradition amongst the Chinese in Malang influences from the West and China were fluidly transformed into mixed local bred expression.

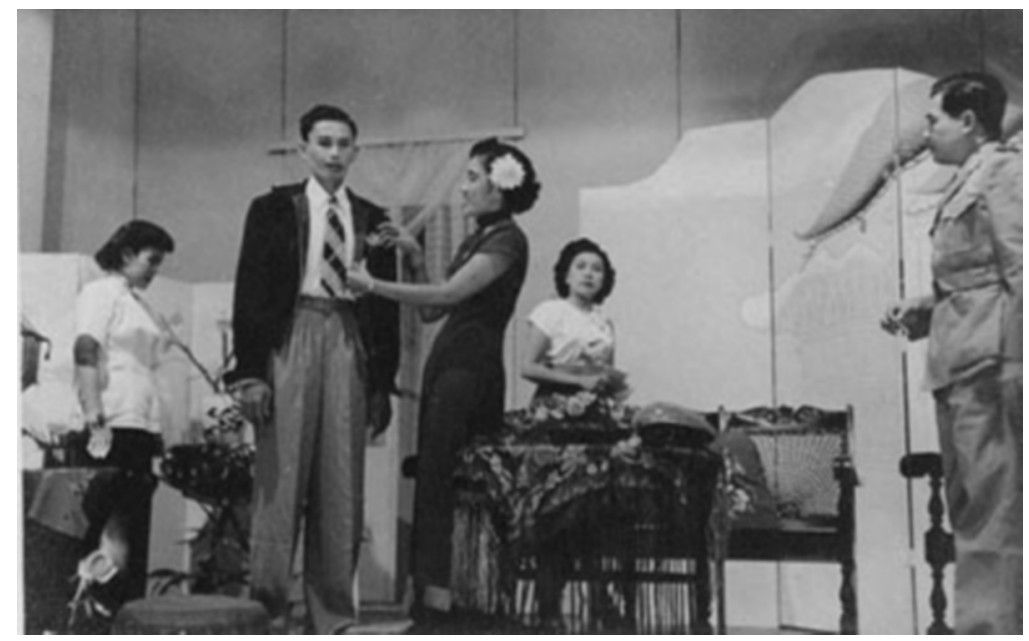

A scene from a 1950s performance of Mawar hutan. (courtesy Panca Budhi Social Organization, Malang)

26 See the manuscript of Mawar hutan by Chen Chuen (n.d.). The identity of the Chinese playwright was not known. 
For Malang Chinese who did not fancy Western dance, Mandarin art or the modern toneel, the option was local performance forms. Among the genres of local performing arts that attracted the interest of the Malang peranakan Chinese were ketoprak and ludruk, genres of folk comic theatre that use East Javanese dialect. The most popular local performance form among the Chinese was wayang orang (a form of dance drama based on wayang kulit). Many older generation Chinese who migrated to Malang from surrounding villages and small cities missed the wayang orang shows that they used to watch in their home villages. Therefore, when the all-Chinese wayang orang theatre was founded by some board members of Ang Hien Hoo in Malang in 1953, it was enthusiastically received by the Chinese in Malang. Hiring a Javanese dance and gamelan music trainer and wayang orang instructor from Yogyakarta, this amateur club recruited dancers, players, and gamelan players from all walks of life within the Chinese communities. ${ }^{27}$ On 24 December 1956 the group made news as it performed in Solo in the very home of wayang orang, at the theatre used by the top wayang orang company in the country, Sriwedari. The two-night performance played to a full house, as the Solo audience was curious to see how the Chinese from East Java performed their traditional art. ${ }^{28}$

Wayang orang activities of the Malang Chinese received strong sponsorship from cigarette companies there. Liem Ting Tjwan, the owner of Orong-Orong cigarette company, sponsored the Ang Hien Hoo group's participation in the national wayang orang competition in Solo in 1962. ${ }^{29}$ The popularity of the Ang Hien Hoo wayang orang performances led to an invitation for the group to perform in front of President Soekarno in his Jakarta palace in 1960. This was the occasion when Nelly Ie, the Ang Hien Hoo prima donna who enthralled the president with her mastery of the Javanese art, received her new name Ratna Juwita, by which she was later widely known.

Hobby club activities in various forms mentioned above did not exhaust the cultural expressions of 13,000 peranakan and totok, who made up the Chinese population of Malang in 1954 (barely $5 \%$ of the total population of the city). ${ }^{30}$ As both pastime and profession,

27 Including students, housewives, shop attendants and employers and employees.

28 KSN 1956. Rustopo (2007) noted that from the 1950s to early 1960s it was common to find peranakan wayang orang groups, even in remote villages.

29 In the 1962 competition, Ang Hien Hoo competed with 17 other non-profit wayang orang groups from all over Java (Jakarta, Bandung, Solo, Yogyakarta, Surabaya, Purwokerto and Kediri) plus one from Pekanbaru, five of which were also led and played by peranakan dancers. See Rustopo 2007:155-6. 30 Figures taken from the table in Gapar Wirjosoedibjo et al. (1954:74) showing the growth of Malang population (only 3 categories are given; Indonesian, Foreign Orientals and Foreign Europeans). The approximate number of Chinese mentioned in this paper is based on the number of 13,088 Foreign Orientals out of the 270,048 population total. 
these cultural activities encompassed the diverse taste of a heterogeneous population, from the China oriented, to Dutch educated, Malay modernists, and lovers of indigenous performing arts. ${ }^{31}$ Although the Malang Chinese hobby clubs were mostly exclusive from, by and for the Malang Chinese communities - there were some points of convergence. ${ }^{32}$ Ang Hien Hoo wayang orang theatre was one such meeting point. The Ang Hien Hoo wayang performances drew together totok and peranakan, and a broad general audience as well. These cultural activities provided space for the peranakan Chinese not only to socialize among themselves, but also to engage in charity and fundraising. They served as one channel by which the Chinese inhabitants and middle-sized companies owned by the Chinese circulated part of their money and profits in cultural philanthropy.

\section{GENJER-GENJER: CULTURAL POLITICS IN THE $1960 \mathrm{~S}$}

The early 1960s in Malang was marked by the growing involvement of political parties as patrons in the arts and culture scene. Among the Malang Chinese ${ }^{33}$ there was a noticeable polarization towards left and right wing politics. The situation was intensified by the political climate of Soekarno's 'Crush-Malaysia' and anti-West campaigns in 1963.

In his written address for the 50th anniversary book of the Malang municipality in 1964, the then Mayor of Malang, Koesno Soeroatmodjo evoked this sense of crisis, when he appealed to all state and private organizations 'that claimed to be the instruments

31 Outside these Chinese clubhouses and cultural associations, there are clubs belonging to other diasporas. Mingki Hadi Soesastro, who was raised in Malang in the 1950s, remembered that the remaining small Dutch communities in Malang 'through the Kunstkring continued to organize various cultural activities, including plays (toneel)', one of which was a mystery play in Dutch called Ebbenhouten oliefant (Ebony elephant) in the mid-1950s (Hadi M. Soesastro 2008). The Dutch also had their SAVAM (Sport en Amusement Vereniging also known as ANIEM for Algemeene Nederlands-Indisch Electrisch Maatschappij, Malang, Association of Sports and Amusement Association of Malang Netherlands Indies Electric Company) and the Vereniging voor Huisvrouwen (Housewives' Club). The Indian diaspora had the Indian League Pusat Malang.

32 Other than these more or less exclusively Chinese clubs, there was the Malang Rotary Club, also an elite group engaging in social and cultural philanthropy, consisting of Europeans, Chinese and Indonesians. The Rotary Club was suspended in 1964 during the anti-imperialism campaign, (Tjia Tjoen Liem and Tjia Liang Koei, interview, Bandung, 31-1-2009).

33 From 1963, the Chinese Indonesians were grouped as 'WNI Keturunan' in the municipal statistics to differentiate them from those holding Chinese citizenship who were placed in the category of 'WN Asing'. Although the term 'WNI Keturunan' initially meant Indonesian citizen of [foreign] descent, the term was eventually used to refer solely to Indonesian citizens of Chinese descent. In Malang in 1963, the number of WNI Keturunan had doubled since 1954 from 13,088 to 26,655 of the total 1963 population of 412,698 (Soetikno 1969:117). 
of the Indonesian revolution, to raise awareness towards the holy duty and calling - especially in this trying time during economic difficulties and in the spirit of confrontation against imperialism and neocolonialism à la the "Malaysia project". ${ }^{34}$ That 'holy duty' was to come together as a united front to face the challenges of the time. ${ }^{35}$ When Kusno mentioned the united front, he was referring to Soekarno's concept of NASAKOM (Nasionalisme-Agama-Komunisme) the fusion of the nationalism, religion and communism. The united front was crucial, for Soekarno had conjured up for Indonesia quite formidable enemies, by denouncing Malaysia's independence as a British neo-colonial ploy and pulling out of the United Nations.

On the ground, however, the nationalist, religious and communist fronts were not easily united. In fact, towards the middle of the 1960s the competition between the forces was keenly sensed, even in the realm of the arts. The main promoters of arts and culture in Malang during this Confrontation era of the early 1960s were not club houses, but religious based institutions, schools, social political organizations and political parties, especially their youth sections, which were competing with one another in mobilizing the Malang youth. The Chinese youth were spread in different groups, such as Perhimpunan Mahasiswa Indonesia (PERHIMI, Indonesian University Students' Association), ${ }^{36}$ Perhimpunan Mahasiswa Katolik Republik Indonesia (PMKRI, Indonesian Catholic Students' Association), Pemuda Katolik (Catholic Youth) or the Gerakan Mahasiswa Kristen Indonesia (GMKI, Indonesian Protestant-Christian Students' Movement). On national holidays, these youth organizations would be out in force, competing against one other by putting forth the best of their marching drum bands, a popular activity amongst youth organizations, which was in tune with the spirit of the time.

Different artistic preferences were apparent in the kinds of arts championed by the different political organizations. In cultural festivals, the leftist groups would show folk art and dances depicting the lively spirit of fisherfolk, workers and farmers. One of the most popular such dances was the Genjer-genjer dance, depicting village women harvesting genjer, water hyacinth that grows wild on river banks, turning the wild plants into food during famine. The Gen-

34 jjang mengaku dirinja sebagai alat revolusi Nasional Indonesia, menjadari tugas dan kewadjiban jang sutji ini, lebih2 dalam keadaan seluruh bangsa dan Negara Republik Indonesia diliputi oleh suasana kepribadian keprihatian dalam mengatasi kesulitan2 dalam bidang ekonomi dan disampingnja diliputi oleh suasana konprontasi dalam usaha kita bersama untuk mengganjang sifat2 imperialisme, kolonialisme dan neo-kolonialisme ala projek "Malaysia".' (no page).

35 See 'Kata pengantar Walikota Malang' in Mochamad Hanafiah et al. 1964.

36 PERHIMI evolved from the prewar Ta Hsueh Hsueh Sheng Hui, and was affiliated with BAPERKI. 
jer-genjer dance symbolized the struggle and resilience of the common people. Leftist art, in line with PRC artistic taste of the time, was often shown together with dances performed by students of Chinese schools, or Chinese dancers from the mainland who were touring under the sponsorship of the Chinese embassy.

The PPI and Pemuda Rakyat were also active in promoting indigenous performing arts, especially ludruk, which had wide appeal among the grass roots and the common people. Realizing that their elitist Western art lacked grass root appeal, the Malang PMKRI formed their own ludruk group. One of the popular ludruk plays in Malang and Surabaja was Pak Sakerah (Mr Sakerah), the story of a Madurese underdog working in a sugar plantation, who rebelled against Dutch colonial repression. ${ }^{37}$

In the meantime, Siauw Giok Bie used the political space offered by BAPERKI, an organization that focused on issues of Indonesian citizenship. ${ }^{38}$ Nationalistic and loyal to President Soekarno, BAPERKI was keen to keep the NASAKOM unity, and greatly resented the Catholic Chinese withdrawing their support. Under the leadership of Siauw Giok Tjan in Jakarta and Siauw Giok Bie in Malang, BAPERKI fought for equality for all citizens, regardless of race, religion and ethnicity, and fought against discrimination of any kind. BAPERKI activists felt that they received support from the leftist leaning organizations, and were keen to work together with them. This in turn alienated many peranakan Chinese people, who opposed the leftist and communist front. Some peranakan literati, such as Tan Sien Giok, who did not feel at home with either the right or the left, preferred to support other national political parties, such as the PNI, which had a strong base in Malang.

By the mid-1960s, the split amongst the close-knit peranakan Chinese took the form of a polemic between those who were supporting integration versus those arguing for assimilation. The BAPERKI group belonged to the first camp, believing that it was the right of every citizen to retain his or her cultural tradition, including one's name and cultural orientation. The proponents of assimilation, most of them of Catholic background, believed that assimilation to the indigenous population was the best way to solve the Chinese "prob-

\footnotetext{
37 Henri Supriyanto (interview, Malang, 12-10-2008).

38 Oei Tjoe Tat noted that in the 1950s BAPERKI got much support from peranakan Chinese in Indonesia, and managed to open branches in small cities; up to 100 branches altogether, including in Malang. During the first Indonesian general election for the House of Representatives in 1955, BAPERKI apparently got votes from non-Chinese citizens as well, as the number of votes they got in Jakarta, Tangerang, Malang and Lawang exceeded the number of registered Chinese Indonesian citizens voters in those cities (Oei Tjoe Tat 1995:84). See also Pramoedya Ananta Toer and Stanley Adi Prasetyo 1994.
} 
lem'. The integrationists, who were keen supporters of the antidiscrimination policy, accused the assimilationists of robbing the Chinese of their right to keep their names and cultural traditions. Many of the assimilationists, who proposed the changing of Chinese names, were already culturally assimilated and had long since adopted local indigenous names. For them, the cultural approach was the best way. A journalist working for Terompet Masjarakat (People's Trumpet) in 1960s, Oei Hiem Hwie, who was then in his 30s, witnessed this growing tension among Malang senior activists, noting however, that after fiery verbal debates over integration versus assimilation, Siauw Giok Bie of the BAPERKI and Tan Hong Bok from the Catholic Party (who happened to live side by side on the same street) would play tennis games together. ${ }^{39}$ In fact, taking the example of these two neighbours, there was little difference between the lifestyle of an integrationist and an assimilationist. They were both Dutch educated, their children were sent to Catholic or Christian schools, they played piano and loved watching the Ang Hien Hoo wayang orang performances. Young children of Chinese families, at school or in the dance clubs, learned various traditional dances.

From 1962 onwards, there were no more ballroom dances and Hawaiian music bands for young peranakan Chinese, as Soekarno banned Western 'ngak-ngik-ngok' music, considering it to be the polluting influence of capitalist and imperialist culture. The Koes Ploes band, known as 'the Indonesian Beatles', was banned, along with tight-fitting bell-bottom pants then fashionable among teenagers. The PPU was closed (around that time) as were Western associations such as the Rotary Club. To fill the vacuum, new dance clubs with a nationalist orientation were formed, one of which was the Kuala Deli Dance Workshop founded by Colonel Soetrisno, using his house in Jalan Wilis as a studio. My three sisters and I and the Soetrisno's six children were members of this dance workshop. Apart from the Serampang dua belas, the Sumatran social dance popularized by Soekarno, we learned the modern social (pergaulan) dances, the Indonesian version of ballroom dance and new forms of Indonesian modern dance, following the trend being set by Bagong Kussudiardjo in Central Java. ${ }^{40}$ This genre, then called tari kreasi baru (new creations), interpreted traditional dances and fused them with the free movement of modern ballet. The most popular dance was the Indonesia indah or Beautiful Indonesia dance.

39 Oei Hiem Hwie, interview, Surabaya, 19-6-2009.

40 Bagong Kussudiardjo (also spelt Kussudiardja) taught dance in Malang in 1956-1957, when he was living there while based at the Djawatan Kebudajaan office in Surabaya (Bagong Kussudiardja 1993:145). 
The political tension that was rising in the months of 1965 at the national level was spreading to all corners of Indonesia, including the municipal city of Malang, affecting its vibrant cultural activities. A Catholic priest with a strong totok background, Father Wang, then the headmaster of St Joseph School (known amongst the Chinese as Hwa Ing), created an uproar when he refused to give permission for his students to be involved in a cultural event organized by the left-leaning student association, the PPI. ${ }^{41}$ There were strong feelings amongst the anti-communist Chinese Catholics that the PPI cultural activities were 'not just angklung and zangclub (singing clubs)' (Junus H. Jahja 2009:68), but promoting communist ideology. On the other hand, for those with affiliation towards the PRC, Father Wang was seen as the agent of Kuomintang. There were many demonstrations against Father Wang and his anti-communist policies, demanding his deportation from the country. ${ }^{42}$

By mid-1965 there were whispered rumours that the PKI and leftist organizations had blacklisted the names of right-wing activists. Living in a close-knit neighbourhood, peranakan Chinese from both sides warned each other to be watchful. No one was ready, however, for the 30 September-1 October 1965 military turmoil and its bloody aftermath. In Malang, communist cleansing was carried out by both the military and civilians, unchecked, against anybody who was accused, often out of personal spite, of being communist or leftist. The highest number of casualties was in the southern part of Malang. ${ }^{43}$ Terror spread among the Chinese communities, especially BAPERKI and the left-leaning activists. In 1965-1966, Siauw Giok Bie, then Chair of BAPERKI in East Java, was detained. Tan Hwie Liong, the most respected figure amongst the peranakan Chinese and patron for charity and social-cultural philanthropy, disappeared..$^{44}$ The Malang

41 Harry Tjan Silalahi also gave an account of the threats against priests and religious leaders in small cities in Central and East Java (Soedarmanta JB 2004:109). From Harry Tjan Silalahi's perspective, Father Wang from Malang was under intense terror (Silalahi, interview, 16-4-2009). According to Oei Hiem Hwie, on the other hand, it was the priest, being from Taiwan, who exercised a strong hand against PPI members, and after 1965 gave their names to the military forces (interview, Surabaya, 19-6-2009).

42 Siauw Giok Tjhan (1981) discussed similar incidents in Kalimantan, whereby a Catholic Bishop by the same name, Father Wang, challenged the effort to unite the nationalist, religious and communist forces.

43 On 31 July 1968, the Malang local parliament (DPRD Gotong Royong) - in the name of all inhabitants of Malang - issued a decree thanking the Military District Commander 0818 and his apparatus for 'repressing the remnants of G30S/PKI', especially in the southern part of Malang. The decree gave funding of 10 million rupiah for the 'territorial operation' (See Himpunan Perda 1972).

44 Stanley, interview, Jakarta, 30-7-2009. 
branches of the mass media considered to have any left-leaning content were banned, including the Terompet Masjarakat. Oei Hiem Hwie, one of its reporters, was detained and later sent to Buru island. With communist China now seen to be supporting the "communist rebels', Chinese speaking schools such as Ma Chung and Ta Chung were closed, their buildings confiscated and turned into military headquarters, their teachers confined in school buildings for days before being released. Dancers, singers, musicians, wayang shadow-puppet masters and ludruk and ketoprak players who had performed in leftist cultural activities were detained. Many disappeared without trace, including a dance trainer from the Kuala Deli Dance Workshop. The Ang Hien Hoo wayang orang group stopped its activities. Chinese-owned industries, including cigarette companies, which had been patrons of arts and culture for almost all organizations from the left and right, had to justify their funding policies and prove their neutrality.

Amongst Malang Chinese, there were efforts by those who survived the red cleansing to look for others who disappeared, but on the whole, it was everyone for his or her own safety, for no one was quite safe. In what was called as apel siaga (alert assembly), students, workers, and organizations were gathered - their names checked to profess loyalty to Pancasila, the national ideology. It was in such an atmosphere that the Malang Chinese representatives gathered on 18 April 1966 and read the speech that stressed that 'there are no Indonesian citizens of Chinese descent who do not wish for the total unity and integrity of the Indonesian nation' and 'who do not want to work hand in hand in order to contribute all their energy and thought for their beloved country and nation Indonesia' ${ }^{45}$ The apel siaga of the Malang Chinese showed the great pressure they felt. ${ }^{46}$ According to Junus Jahja, a minister, (unnamed), publicly

45 [b]ahwa tidak ada seorang Indonesia keturunan Tionghoa jang tidak sungguh-sungguh ingin adanja persatuan dan kesatuan jang bulat dalam seluruh bangsa Indonesia dan bahumembahu seluruhnya ingin sama-sama mengabdikan tenaga, pikiran dan segala-galanyja untuk kepentingan Nusa dan Bangsa Indonesia jang sangat ditjintainja.' (Pidato ketua 1966:1).

46 Catholic activists in Malang, most of them peranakan Chinese, although wary of the slaughter and detention of innocent victims, were strongly anti-communist. Assimilationist in their approach, they worked in close coordination with their national counterparts in Jakarta, such as Sindhunata from the Lembaga Persatuan dan Kesatuan Bangsa (LPKB, Institute for National Union and Unity), I.J. Kasimo (Catholic Party), Harry Tjan Silalahi and Cosmas Batubara (PMKRI) (Harry Tjan Silalahi, interview, 16-4-2009). Father Beek SJ, a Dutch Jesuit priest in Jakarta, conducted rigorous one-month training for Catholic youth to prepare them to fight communism and defend the national ideology of Pancasila. Soebianto (interview, September 2008) remembered how he accompanied Father Beek to many cities, including Malang, to brief Catholic students to join the anti-communist front with other right wing forces (HMI, PMII, Muhammadiyah Youth), which later in 1966 merged into Kesatuan Aksi Mahasiswa Indonesia (KAMI, Indonesian Student Action Union) and Kesatuan Aksi Pemuda dan Pelajar Indonesia (KAPPI, Indonesian Youth and Student Action Union). 
questioned the loyalty of the Chinese Indonesians in a huge mass rally (rapat raksasa) 'right after the GESTAPU (Gerakan Tigapuluh September, or the 30th September incident) in October 1965 in Jakarta' (Junus H. Jahja 2009:95).

Cultural and arts organizations headed by the Chinese people who were under detention had to do housecleaning. During the 1965 turmoil, Ang Hien Hoo was led by Siauw Giok Bie, the detained chair of BAPERKI. To save the organization, he was replaced by an acting director. In 1981 Colonel Ong Tjong Bing, a dentist who served in the army, was appointed as the new chair, and the name of the organization was changed to Yayasan Panca Budhi. ${ }^{47}$ Other arts and cultural groups accused of leftist orientation were banned. The Genjer-genjer song was no longer sung, as it was considered to be GERWANI's song (Gerakan Wanita Indonesia, Indonesian Women's Movement, the women's organization affiliated with the Indonesian Communist Party) (Soedarmata 2004:110). The 1965 turmoil had a grave impact on folk theatre, especially ludruk. While all LEKRA and PKI affiliated ludruk theatre was banned, the remaining ludruk groups in Malang were too afraid to perform. Only in 1967 did ludruk theatre reappear, under the supervision and direction of different units of the Brawijaya military regiments (Henri Supriyanto 1992:14). From 1967 onwards, party and mass organizations in Malang and the religious organizations, were doing what they termed as 'consolidation' through arts and cultural festivals. Peranakan Chinese dancers who joined the Kuala Deli Dance Workshop and the PMKRI or Catholic Youth arts and theatre clubs and other youth theatre and arts club from the Muslim and nationalist groups were often invited to perform in these cultural festivals. Until the late 1960s and early 1970s, the Education and Culture section of the Malang Municipality sponsored such festivals and organized theatre and poetry competitions with nationalistic themes, channelling the energy left from the 1965-1966 ideological struggle amongst the political and mass organizations.

By 1972, however, when the New Order Government under Soeharto ordered the fusion of mass organizations and political parties, the cultural life and expression of mass and political organizations in Malang had dwindled. This was the beginning of the New Order cultural politics. J.A. Nurtjahjo, a Catholic activist of 1960s, suggests three reasons for the decline of cultural activities in Malang in general. ${ }^{48}$ First was 'the loss of a strong ideological opposition to 
compete with'. With the leftist cultural groups out of the scene, the drive to fight was gone. Second, was the decline of financial support from Malang businesses and industries, which, traumatized by the penalty they got for sponsoring the wrong camp, were no longer keen on cultural philanthropy. Third, the fusion of political parties had robbed smaller organizations, which used to have their own arts sections, of their mechanisms for mobilizing arts and cultural activities. Together, these factors worked to depoliticize the arts and cultural scene in Malang, especially among the Chinese.

CONCLUSION: THE DYING BREED?

The cultural activism of the Malang Chinese from the AMT generation in late 1947 to the late 1960s reflects the dynamics of minority citizens embroiled in the nation building process. Shaped by the larger forces that surrounded them - the legacy of Dutch colonial policy and Japanese Occupation, the Indonesian independence revolution and the repercussions of Indonesia's own 1965 'Cold War' - the Malang Chinese, through their cultural politics, emerged as agents who actively negotiated, engaged and in a way also shaped those very forces.

In terms of nationalism and the cultural assimilation of the peranakan Chinese, the cultural history of the Malang Chinese might not be too different from those of other cities in Java, such as Yogyakarta, Surakarta, Semarang or Surabaya. What comes to the surface in the Malang context is not so much the degree of cultural assimilation, but the intensity of the cultural politics of the Chinese, closeknit within the small public sphere of the Malang environment, and at the same time vibrantly diverse and full of contestation. As a residential and resort area, Malang had served as an escape and at the same time nursing bed for many Chinese of neighbouring areas to nurture their cultural, artistic and political aspirations. The influence of the older generation of politically active Chinese intellectuals, such as Siauw Giok Tjan and Go Gien Tjwan, was significant in setting the cultural climate. Compared to Surabaya as a bustling port city, Semarang with its long history of the Chinese trading communities, or Solo or Yogyakarta with their strong Javanese kraton (palace) aura, Malang, which was named a municipality only in 1914, had a legacy as a Dutch residential town. Known as a favourite place for Chinese families from the surrounding areas in East Java to send their children for primary and secondary education in the Christian schools inherited from the Dutch, Malang 
served as a 'transit' city for Chinese intellectuals and cultural and political activists, who were at home in the modernist and hybrid mix of the Malay-Dutch-Chinese-Javanese milieu. In the words of one AMT crash course alumni: 'Compared to Surabaya, Semarang, Yogyakarta and Surakarta, Malang was a young city. The society was as young as the city. The older generation in Malang had mostly graduated from MULO and spoke Dutch. The younger generation was considered to be modern.' ${ }^{49}$

The quote below from the bi-weekly magazine Liberty (published in Malang from 1946), explaining the symbol of the dove on its cover, captures the modernist attitude of the majority of Chinese transiting in Malang:

Real freedom gives mental freedom, which means freedom from all kinds of ties or bondage. Examples of mental bondage are arrogance, snobbism, chauvinism, religious fanaticism, and fanaticism in clinging to tradition, all of which hamper individuals from being free. ${ }^{50}$

One question remains, whether this plural culture, fluid and easily adapting to the new surroundings, was transient. The colonial legacy amongst the Dutch educated Malang peranakan Chinese was expressed in the fluid mix of the 'jolly 50s', which gave way to the Soekarnoist era of the nationalist modernist culture of the 1960s. Not covered in this paper, but implied from the career path of the AMT crash course alumni, was the cultural absorption of the Malang peranakan Chinese into the New Order depoliticizing cultural politics, which banned any trace of Chinese-ness. When the Reformasi age began in 1998, what emerged in Malang as well as in other places in Indonesia was the celebration of Chinese-ness which was far removed from the hybrid cultural expression produced in the complicated historical process. With the rise of China as a global economic force and the rising enterprise of Chinese businesses with stronger cultural orientation towards the mother land, what appeared in the public space in many urban centres in Indonesia, was stereotypical representations of Chinese culture,

49 'Kota Malang itu relatif kota muda, kalau dibandingkan dengan Surabaya, Semarang, Yogyakarta...Karena kotanya muda, masyarakatnya juga muda. Angkatan tua di Malang ratarata lulusan MULO, berbahasa Belanda. Anak-anak Malang di kenal modern'. (From the AMT Crash Course Alumni FGD, Jakarta 21-2-2009).

50 'Merdeka sedjati berikan djoega kemerdekaan bathin, djadi bebas dari segala matjam ikatan tau kekangan. Ikatan bathin adalah beroepa penjakit temahe, gila hormat, chauvinism, koekoeh igama, koekoeh traditie jang semoeanja menghalangi manusia hidoep merdeka'. (Liberty 167, 15-2-1946). 
such as the replica of the Great Wall. With the BAPERKI political activists erased, and the peranakan Chinese New Order assimilationist intellectuals retreating, will the Malang Chinese and their mixed culture become 'the dying breed', a relic for the Malang Tempo Doeloe annual celebration? ? $^{51}$

The celebration of the stereotypical Chinese-ness, however, as many have argued, might not be the only cultural path to the future (Tan 2008). Amongst the younger generation coming out of Malang are leading Indonesian intellectual and cultural workers who combine modernity with local touch in hybrid forms. ${ }^{52} \mathrm{~A}$ number of young intellectuals who passed through Malang, such as the late Mingki Hadi Soesastro, Ariel Heryanto, Stanley Adi Prasetyo, and Esther Indahyani, engaged critically with the economic, social and political structures and moved beyond the borders of fixed cultural identities. ${ }^{53}$ In the meantime, small people worked quietly to continue the cross cultural legacy. In one corner in Malang, a mother in charge of the wayang orang section of the Pancabudhi Foundation (then Ang Hien Hoo), gathered all resources to revive the wayang orang tradition among the younger generation. ${ }^{54}$ New creative expressions continue to be displayed. In a play called The birth of Setyaki staged for one of the Malang Tempoe Doeloe festivals, the tiger who was supposed to devour the protagonist Setyaki was replaced by a barongsai player from the Eng An Kong temple..$^{55}$ There are strong indications that Malang, as a microcosm of Indonesia, will remain a site for complex, plural cultural expression of the Chinese as Indonesian citizens. A new chapter is yet to be written.

51 From the words of one AMT crash course alumni, FGD, 21-2-2009: 'We - the generation who could speak Dutch and experienced the colonial, revolution, independence and the reformation - we are a dying breed'.

52 While the renowned architect, Han Awal, belonged to the AMT generation, amongst the younger generation of Malang Chinese architects are Budiman Hendro Purnomo (Tugu Hotel, Malang and the central library of the University of Indonesia), and Hidayat Endromukti (Griya Cakra Hotel, Malang). In the field of music there is conductor Paul Imam Zacharia, who promotes interfaith dialogue.

53 The late Mingki Hadi Soesastro, who became one of the leading CSIS political economists during the New Order, was the son of Tan Sien Giok, the director of the Paragon Press and one of the editors of the Liberty magazine when it was published in Malang. Ariel Heryanto, proponent of contextual literature in the literary debate of 1970s, is now Assistant Professor at the Australian National University, Canberra; Stanley Adi Prasetyo is a writer and human rights activist. Esther Indahyani is an awardee of the Yap Thiam Hien award for her human rights advocacy in fighting for the May 1998 victims.

54 Now only a small percentage of the wayang orang players are Chinese, mostly the children and grandchildren of the previous Ang Hien Hoo fans and players (Sinta Dewi, interview, Malang, 10-07-2010).

55 Ong Tjong Bing, interview, Malang, 9-7-2010. 
REFERENCES

d'Amour, M. (pen name of Njoo Cheong Seng)

1951 Malang mignon; Hoakiau melodrama dalam 4 babak. Malang: [s.n.]

Bagong Kussudiardja

1993 Sebuah autobiografi. Yogyakarta: Bentang Intervisi Utama, Padepokan Press.

Chen Chuen

n.d.

Mawar hutan; Sandiwara dalam empat babak. Diterjemahkan oleh Teng Ying Siang, dipertundjukkan oleh Perhimpunan Pergaulan Umum. Malang: Stensil Roneo Malang. [Manuscript.]

Chishohn, Dianne

2001 'The city of collective memory', GLW, A Journal of Lesbian and Gay Studies 7-2:195-243.

Coppel, Charles A.

1983 Indonesian Chinese in crisis. Kuala Lumpur: Oxford University Press. [Southeast Asia Publications Series, Asian Studies Association of Australia 8.]

1994 Tionghoa Indonesia dalam krisis. Jakarta: Pustaka Sinar Harapan.

Didi Kwartanada

2002 'Competition, patriotism and collaboration; The Chinese businessmen of Yogyakarta between the 1930s and 1945, Journal of Southeast Asian Studies 33-2 (June):257-77.

Gapar Wirjosoedibyo et al.

195440 Tahun kota Malang. Malang: Panitya Peringatan 40 Tahun Kota Malang.

Hadi M. Soesastro

2008 'A short write up about myself'. [Manuscript, September 2008.]

Heidhues, Mary F. Somers

1988 'Citizenship and identity; Ethnic Chinese and the Indonesian revolution' in: Jennifer W. Cushman and Wang Gung $\mathrm{Wu}$ (eds), Changing identities of the Southeast Asian Chinese since World War II, pp. 115-38. Hongkong: Hongkong University Press.

Henri Supriyanto

1992 Lakon ludruk Jawa Timur. Jakarta: Grasindo. 
Himpunan Perda

1972 Himpunan Perda keputusan DPRGR kabupaten Malang 19681971. Kabupaten Malang.

Junus H. Jahja

2009 Catatan orang Indonesia. Jakarta: Komunitas Bambu.

KSN

1956 'Nonton wayang orang Ang Hien Hoo', Pancawarna.

http:/ / tjamboek28.multiply.com/photos/album/164/

Wajang_orang_ANG_HIEN_HOO, (accessed 14-8-2009).

Leo Suryadinata

2002 Negara dan etnis Tionghoa; Kasus Indonesia. Jakarta: LP3ES.

Mochamad Hanafiah et al.

1964 Kota pradja Malang 50 tahun. Seksi penerbitan 50 tahun

Kotapradja Malang.

Myra Sidharta

2004 Dari penjaja tekstil sampai super woman; Biografi delapan penulis peranakan. Jakarta: KPG.

Muhammad Umar Syadat Hasibuan

2008 Revolusi politik kaum muda. Jakarta: Yayasan Obor Indonesia.

Pidato ketua

1966 'Pidato ketua panitia apel siap siaga warga negara Indonesia kota-madya/kabupaten Malang, tanggal 18 April 1966’.

[Manuscript.]

Pramoedya Ananta Toer and Stanley Adi Prasetyo

1994 Memoar Oei Tjoe Tat; Pembantu Presiden Soekarno. Jakarta:

Hasta Mitra.

Rustopo

2007

Menjadi Jawa; Orang-orang Tionghoa dan kebudayaan Jawa di Surakarta, 1895-1998. Yogyakarta: Ombak and Nabil.

Sam Setyautama

2008 Tokoh-tokoh etnis Tionghoa di Indonesia. Jakarta: KPG and Chen Xingchu Foundation.

Schaik, A. van

1996 Malang; Beeld van een stad. Purmerend: Asia Maior.

Siauw Giok Tjhan

1981 Lima jaman; Perwujudan integrasi wajar. Jakarta: Yayasan Teratai.

Soebianto, T.B.

2008

'Ringkasan perjalanan hidup'. [Manuscript, 1-10-2008.] 
Soedarmanta, J.B.

2004

Tenggara Orde Baru, kisah Harry Tjan Silalahi. Jakarta: Penerbit PT Toko Gunung Agung TBK.

Soetikno, S.H.

1969

Kotamadya Malang lima puluh lima tahun, 1 April 1914-1 April 1969. Malang: Seksi Penerbitan Buku Petundjuk Kota Malang.

Stanley

2004

'Malang, Tjamboek, dan jaman peralihan', in: Stanley and Arief W. Djati (eds), Tjamboek berdoeri; Indonesia dalem api dan bara, pp. 339-71. Jakarta: Elkasa.

Stanley and Arief W. Djati

2004 Tjamboek berdoeri, Indonesia dalem api dan bara. Jakarta: Elkasa.

Suma Tjoe Sing, L. et al.

1935

Gedenkboek 1910-1935 25 taoen berdirinja Ang Hien Hoo Malang. Malang: Comite Jubileum 25 Taon Vereeniging Ang Hien Hoo Malang.

Tan, Mely G.

2008

'The ethnic Chinese in Indonesia; Issues of identity', in: Mely G. Tan (ed.), Etnis Tionghoa di Indonesia, pp. 156-92. Jakarta: Yayasan Obor Indonesia. 